\title{
Pendampingan Promosi Wisata Gerabah Dengan Media Video di Dusun Pungkang Desa Masbagik Timur
}

\author{
M. Ami Thalib Hermawan ${ }^{1}$, Muhammad Sadaruddin ${ }^{2}$, Sri Wahyuni $^{3}$, Demolinsara $^{4}$, Mariana \\ Ulpa $^{5}$, Sri Shanti Ariani ${ }^{6}$ \\ ${ }^{1}$ Program Studi Ilmu AI Qur'an dan Tafsir, STAI Darul Kamal NW Kembang Kerang \\ ${ }^{2}$ Program Manajemen Pendidikan Islam, STAI Darul Kamal NW Kembang Kerang \\ ${ }^{3}$ Program Manajemen Pendidikan Islam, STAI Darul Kamal NW Kembang Kerang \\ ${ }^{4}$ Program Pendidikan Guru Madrasah Ibtidaiyah, STAI Darul Kamal NW Kembang Kerang \\ ${ }^{5}$ Program Pendidikan Guru Madrasah Ibtidaiyah, STAI Darul Kamal NW Kembang Kerang \\ ${ }^{6}$ Dosen STAI Darul Kamal NW Kembang Kerang \\ *e-mail: atThalib99@gmail.com¹, ,shadarghifari0812@gmail.com², cutesry08@gmail.com³, \\ demolinsara@gmail.com ${ }^{4}$, marianaulpa2462@gmail.com ${ }^{5}$
}

\begin{abstract}
The pottery craft in East Masbagik village has been known for a long time, even to foreign countries. The pottery centers in East Masbagik village are generally known by the community and are only concentrated in one area, namely the Penakak hamlet. Pungkang hamlet is one of the areas as a center for the pottery industry which is important to be published, so as not to experience social jealously and to increase the development of the pottery industry in East Masbagik village. Community service activities carried out are assistance to promorte pottery in Pungkang hamlet with video media, in accordance with current developments in information technology. This research is a field research using the PAR approach (Participatry Action Research), data collection techniques are carried out by means of observation, interviews, documentation and literature study. The methodology used is a qualitative descriptive method which aims to provide an overview of the result of the analysis of community conditions in community service research. The results showed that community service partners, namely POKDARWIS (Kelompok Sadar Wisata) and pottery industry players in Pungkang hamlet, have been able to independently promote their pottery using video media, the public can get $\mathrm{t}$ know the pottery industry not only in Penakak hamlet and the pottery industry players in Pungkang village to gain knowledge regarding how to promote earthenware craft through video media.
\end{abstract}

Keywords: Pungkang hamlet, pottery, promotions, videos

\begin{abstract}
Abstrak
\footnotetext{
${ }^{1}$ STAI Darul Kamal NW Kembang Kerang

2 STAI Darul Kamal NW Kembang Kerang

${ }^{3}$ STAI Darul Kamal NW Kembang Kerang

${ }^{4}$ STAI Darul Kamal NW Kembang Kerang

5 STAI Darul Kamal NW Kembang Kerang

${ }^{6}$ STAI Darul Kamal NW Kembang Kerang
}

Kerajinan gerabah yang ada di desa Masbagik Timur sudah dikenal sejak lama, bahkan hingga ke mancanegara. Sentra gerabah yang ada di desa Masbagik Timur umumnya dikenal oleh masyarakat hanya terpusat di satu wilayah saja yakni dusun Penakak. Dusun Pungkang merupakan salah satu wilayah sebagai sentra industri gerabah yang penting untuk dipublikasikan, agar tidak mengalami kecemburuan sosial dan meningkatkan perkembangan industri gerabah di desa Masbagik Timur. Kegiatan pengabdian masyarakat yang dilakukan adalah pendampingan untuk mempromosikan gerabah dusun Pungkang dengan media video, sesuai dengan perkembangan teknologi informasi saat ini. Penelitian ini merupakan penelitian lapangan (field research) dengan menggunakan pendekatan PAR (Participatory Action Research), teknik pengambilan data dilakukan dengan cara observasi, 
wawancara, dokumentasi dan studi kepustakaan. Adapun metodologi yang digunakan adalah metode deskriptif kualitatif yang bertujuan untuk memberi gambaran dari hasil analisis kondisi masyarakat dalam penelitian pengabdian masyarakat. Hasil penelitian menunjukkan bahwa mitra pengabdian yakni POKDARWIS (Kelompok Sadar Wisata) dan pelaku industri gerabah yang ada di dusun Pungkang telah mampu mempromosikan gerabahnya dengan menggunakan media video secara mandiri, masyarakat dapat mengenal industri gerabah tidak hanya terpusat di dusun Penakak dan pelaku industri gerabah dusun Pungkang mendapatkan pengetahuan terkait cara mempromosikan kerajinan gerabah lewat media video.

Kata Kunci: Dusun Pungkang, gerabah, promosi, video

\section{PENDAHULUAN}

Desa Masbagik Timur adalah desa yang terletak di kecamatan Masbagik, sejak lama desa Masbagik Timur terkenal dengan kerajinan tangannya berupa gerabah. Gerabah merupakan kerajinan yang terbuat dari tanah liat yang kemudian dibakar dan dibentuk menjadi berbagai parabotan rumah tangga dan sebagai dekorasi ruangan. Keterampilan untuk membuat kerajinan gerabah merupakan warisan turun temurun dari orang zaman dahulu. Kerajinan gerabah termasuk dalam seni kerajinan kriya dikarenakan proses pembuatannya menggunakan tangan sebagai alat dasarnya dan mempunyai manfaat dalam kehidupan sehari-hari. Potensi industri kerajinan tangan yang ada di Indonesia sangat besar untuk merambah ke pasar Internasional. Hal ini didukung dengan hasil sumber daya alam Indonesia yang berlimpah sehingga membuat kerajinan yang dimiliki Indonesia sangat beraneka ragam dan memiliki nilai seni yang tinggi ${ }^{7}$.

Gerabah produksi desa Masbagik Timur pernah menjadi komoditas ekspor andalan Lombok Timur yang telah menembus pasar ekspor seperti ke Belanda, Australia, Israel, Uni Emirat Arab, Amerika, New Zealand dan masih banyak lagi. Sementara untuk pasar domestik gerabah Desa Masbagik Timur telah merambah ke Bali, Surabaya, Yogyakarta, Semarang, Makasar, Jakarta dan Medan. Namun Sejak terjadinya peristiwa bom Bali pada tahun 2002 mengakibatkan dampak buruk bagi pendapatan para pengusaha dan para pengrajin gerabah karena pesanan gerabah yang menurun drastis hingga saat sekarang ini masih belum kembali normal ${ }^{8}$.

Supremasi gerabah mulai mengalami penurunan. Angka penjualan yang mengalami penurunan diiringi menurunnya angka produksi gerabah. Lesunya pasar gerabah berimplikasi pada banyaknya kelompok pengrajin gerabah yang menutup usaha mereka dan terpaksa menekuni profesi lain. Walaupun demikian, sekitar 70\% pelaku industri gerabah di dusun Pungkang masih bertahan hidup dengan tetap memproduksi gerabah. Kurangnya nilai ekonomis dan harga bahan baku yang terus mengalami kenaikan pembuatan kerajian gerabah tradisional telah menyurutkan minat generasi muda pada profesi tersebut. Usaha ini harus mendapatkan dukungan agar mampu lestari dan berkembang ${ }^{9}$.

\footnotetext{
${ }^{7}$ Febryandi Bachri Prastyoko, Dahlan Fanani dan M. Kholid Mawardi "Strategi Pemasaran Kerajinan Gerabah yang Berorientasi Ekspor pada PT. Lombok Putri Cinderamata “ Jurnal Administrasi Bisnis (JAB) Vol. 30 No. 1 (2016)

${ }^{8}$ Ririn Febrina "Peranan Pemerintah Desa Terhadap Promosi Kerajinan Gerabah (Studi Kasus di Penakak Desa Masbagik Timur Kecamatan Masbagik Kabupaten Lombok Timur" Skripsi, Fakultas Administrasi Publik Universitas Nahdlatul Wathan Matara m(2020).

${ }^{9}$ Muhammad Rapii dkk, "Pemberdayaan Usaha Pengrajin Gerabah "penakak" Di tengah Covid-19 Di Desa Masbagik Timur” Jurnal ABDIDAS Vol.1 No. 6 (2020).
} 
Saat ini industri gerabah yang ada di desa Masbagik Timur tidak hanya terkonsentrasi di dusun Penakak yang sudah lama terkenal sebagai sentra industri gerabah, namun ada wilayah lain di desa Masbagik Timur yang belum terekspose dengan kerajinan gerabahnya. Dusun Pungkang adalah salah satu sentra gerabah yang masih bertahan hingga saat ini, terbukti dengan berdirinya artshop, showroom dan adanya proses pembuatan gerabah di sepanjang jalan dusun Pungkang.

Berdasarkan peta desa Masbagik Timur, dusun Pungkang terletak di pintu masuk sentra kerajinan gerabah sebelum dusun Penakak. Oleh karena itu eksistensi dusun Pungkang sebagai salah satu sentra gerabah yang masih bertahan hingga saat ini perlu mendapatkan perhatian agar tidak terjadi kecemburuan sosial antar masyarakat di desa Masbagik Timur, kerajinan tangan gerabah telah mampu membantu perekonomian masyarakat dusun Pungkang ${ }^{10}$

Perkembangan informasi dan teknologi (IPTEK) di setiap sektor; budaya, ekonomi, sosial dan agama telah mampu mengubah pola hidup manusia. Sebagaimana diketahui keadaan dunia usaha bersifat dinamis, yang selalu mengalami perubahan yang terjadi setiap saat. Oleh karena itu diperlukan strategi promosi yang efektif untuk memperkenalkan dan mengembangkan UMKM gerabah yang ada di dusun Pungkang ${ }^{11}$. Upaya promosi dilakukan untuk memperluas jaringan informasi terkait eksistensi gerabah yang ada di dusun Pungkang, dengan demikian komunikasi dalam proses promosi harus menempuh cara yang efektif dan dapat diterima oleh konsumen ${ }^{12}$.

Dari uraian di atas, penulis berinisiatif untuk memberikan pendampingan untuk menyelesaikan permasalahan yang ada di dusun Pungkang tersebut berupa promosi wisata gerabah melalui media audio visual yaitu video. Media video dipilih karena mempunyai efisiensi waktu dan peluang ketika memberikan informasi terkait eksistensi dusun Pungkang sebagai sentra gerabah. Di dusun Pungkang konsumen akan menemukan praktik pembuatan gerabah, showroom, artshop.

\footnotetext{
${ }^{10}$ Ponimin, Triyono Widodo, dan Oktaviviana Asmi Nusantari "Pengembangan Desain Gerabah Tradisional Sentra Pagelaran Malang dengan Teknik Aplikasi Serat Alam Melalui Program Kemitraan Masyarakat" Jurnal Imajinasi Vo 1. XIII No. 2 (2019).

${ }^{11}$ Syamsuri "Pola Strategi Promosi Dalam Proses Pemasaran Gerabah Kasongan: Studi Kasus UMKM Sentra Industri Keramik Di Kasongan, Kabupaten Bantul, D.I. Jogjakarta” Jurnal Administrasi Bisnis (JAB)|Vol. 30 No. 1 Januari 2016 diakses di administrasibisnis.studentjournal.ub.ac.id 44.

${ }^{12}$ Karina Rima Melati "Perancangan dan Implementasi Perencanaan Bisnis dan Strategi Promosi bagi Kelompok Rintisan Usaha Mandiri Sanggar Batik Jenggolo dan Sekar Arum di Kota Yogyakarta", Indonesian Journal of Community Engagement Vol. 02, No. 02 (2017).
} 


\section{METODE}

Penelitian ini dilakukan di Dusun Pungkang yang merupakan salah satu dari enam dusun yang ada di desa Masbagik Timur, produk unggulannya yang sudah merambah pasar dunia (baca: ekspor) adalah gerabah. Namun tidak banyak yang mengenal dusun Pungkang sebagai sentra produsen dan distributor kerajinan tangan gerabah. Jenis penelitian ini adalah penelitian lapangan (field research) dengan menggunakan pendekatan PAR (Participatory Action Research). Teknik pengambilan data dilakukan dengan beberapa instrument yaitu observasi yang dilakukan dengan mengamati kondisi objek penelitian secara langsung, wawancara dengan terstruktur dan tidak terstruktur berdasarkan hasil pengamatan di lokasi penelitian, dokumentasi yang didapatkan berupa data-data dari Pemerintah Desa Masbagik Timur dan studi kepustakaan dilakukan untuk mengetahui studi yang sudah ada sebelumnya ${ }^{13}$.

Metode untuk menganalisis data yang sudah diperoleh yaitu dengan menggunakan metode kualitatif. Metode penelitian kualitatif adalah metode yang berlandaskan pada filsafat postpositivisme atau enterpretif, digunakan untuk meneliti pada obyek yang alamiah, di mana peneliti adalah instrumen kunci, analisis data bersifat induktif dan hasil penelitian kualitatif dapat bersifat temuan potensi dan masalah, keunikan obyek, proses dan interaksi sosial $^{14}$. Penelitian kualitatif akan menghasilkan data-data yang bersifat deskriptif yang berbentuk kalimat serta uraian-uraian yang bertujuan untuk menggambarkan, meringkas berbagai kondisi, berbagai situasi atau berbagai fenomena realitas sosial yang ada di masyarakat yang menjadi objek penelitian, dan berupaya untuk menarik realitas itu ke permukaan sebagai suatu ciri, karakter, sifat, model, tanda atau gambaran tentang kondisi, situasi, atau pun fenomena tertentu ${ }^{15}$.

\section{HASIL DAN PEMBAHASAN}

Kerajinan gerabah desa Masbagik Timur merupakan yang tertua di Lombok Timur. Kerajinan gerabah tersebut terus mengalami perkembangan, mulai dari hanya sebagai produk rumah tangga hingga bermacam-macam model, eksistensi gerabah di tengah arus globalisasi harus terus dipertahankan. Untuk itu kerajinan gerabah sebagai tulang punggung ekonomi masyarakat desa Masbagik Timur harus beradaptasi dengan perkembangan zaman, terutama cara untuk mengenalkan dan memasarkan produksi gerabah desa Masbagik Timur $^{16}$.

Pada mulanya gerabah yang ada di desa Masbagik Timur hanya terpusat di dusun penakak saja, namun saat ini eksistensi gerabah sudah meluas ke dusun-dusun lain yang

\footnotetext{
${ }^{13}$ Hidayatul Ahyani, "Peranan Pemerintah Dalam Pengembangan Industri Kecil Gerabah Didesa Banyumulek Kecamatan Kediri Kabupaten Lombok Barat ”Journal Ilmiah Rinjani Universitas Gunung Rinjani Volume 7. No.2 (2019)

${ }^{14}$ Sugyono, "Metode Penelitian Pendidikan (Kuantitatif, Kualitatif, Kombinasi, R\&D dan Penelitian Pendidikan)". Bandung, Penerbit Alfabeta (2019)

${ }^{15}$ H.M Burhan Bungin, "Penelitian Kualitatif : Komunikasi, Ekonomi, Kebijakan Publik, dan Ilmu Sosial Lainnya". Jakarta, Kencana Media Group (2011).

${ }^{16}$ Febryandi Bachri Prastyoko, Dahlan Fanani dan M. Kholid Mawardi "Strategi Pemasaran Kerajinan Gerabah yang Berorientasi Ekspor pada PT. Lombok Putri Cinderamata “ Jurnal Administrasi Bisnis (JAB) Vol. 30 No. 1 (2016).
} 
berada di desa Masbagik Timur. Salah satu dusun yang belum dikenal banyak oleh masyarakat adalah dusun Pungkang, bahkan gerabah dusun pungkang sudah berhasil menembus pasar Internasional.

Agar keberadaan gerabah yang ada di dusun Pungkang dapat dikenal luas, maka penulis melakukan kegiatan pengabdian masyarakat yakni promosi gerabah dusun Pungkang dengan menggunakan media video untuk mengenalkan gerabah dusun Pungkang dan menarik perhatian dari wisatawan mancanegara maupun wisatawan domestik ${ }^{17}$. Promosi (promotion) adalah usaha atau upaya untuk memajukan atau meningkatkan: misalnya untuk meningkatkan perdagangan atau memajukan bidang usaha. Promosi berasal dari kata promote dalam bahasa Inggris yang diartikan sebagai mengembangkan atau meningkatkan. ${ }^{18}$

Pelaksanaan pengabdian masyarakat pendampingan promosi lewat media video ini dilakukan dalam tiga tahap, yakni tahap persiapan, tahap produksi video, dan tahap refleksi atau evaluasi ${ }^{19}$, sebagai berikut:

\section{Tahap Persiapan}

Dalam tahap ini penulis melakukan observasi di lokasi penelitian yakni dusun Pungkang.

Kemudian mengumpulkan bahan dan instrument untuk produksi video, diantaranya:

a. Surat Perizinan

Untuk melakukan penelitian pengabdian masyarakat di desa Masbagik Timur, penulis melakukan koordinasi dengan pihak pemerintah desa Masbagik Timur dan kegiatan ini disetujui oleh pihak pemerintah desa Masbagik Timur dengan dikeluarkannya surat izin penelitian pengabdian masyarakat dengan pendekatan PAR (Participatory Action Research) di dusun Pungkang desa Masbagik Timur.
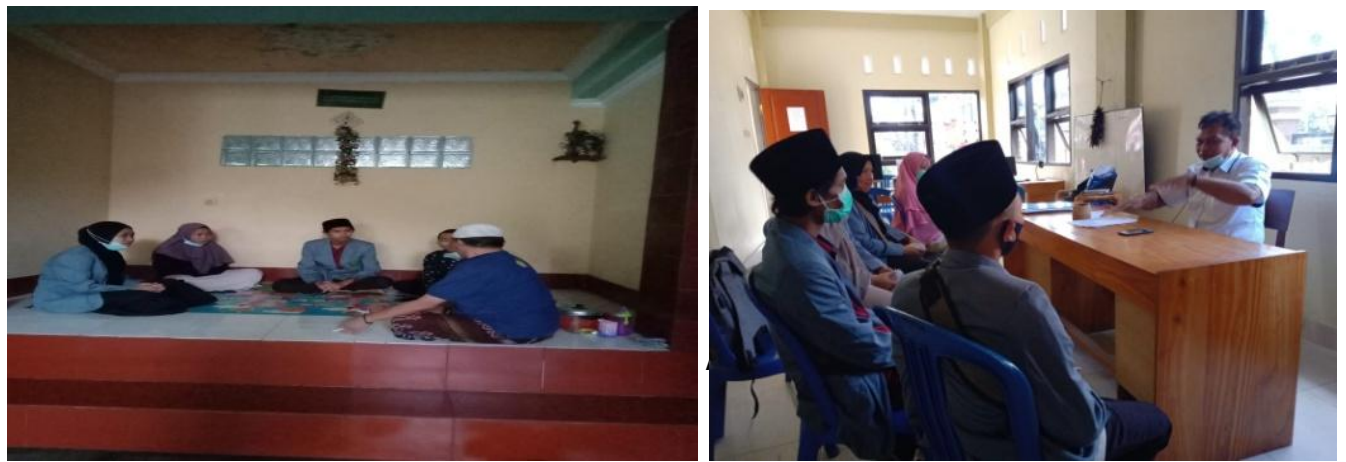

Gambar 1 di atas merupakan koordinasi dan konsultasi untuk kelancaran program yang direncanakan. Pemerintah desa dan kepala wilayah menyambut positif kegiatan pengabdian ini.

b. Kamera dan Video Editor

Untuk melakukan produksi video promosi, penulis mempersiapkan alat produksi berupa camera (handycam) dan Video Editor dengan menggunakan aplikasi

\footnotetext{
${ }^{17}$ Freddy Rangky, "Strategi Promosi Yang Kreatif Dan Analisis Kasus Integrated Marketing Communication" Jakarta. Penerbit Gramedia Pustaka Utama (2009).

${ }^{18}$ ibid

${ }^{19}$ Luluk Tri Harnie, Jum 'eh Dan Alexandra Hukom, "Pendampingan dalam Memasarkan Produk Hasil Usaha UKM melalui Penggunaan Media Sosial di Kabupaten Gunung Mas Kalimantan Tengah" Jurnal ENGAGEMENT Jurnal Pengabdian Kepada Masyarakat Vol04, No. 01: 51 - 59 (2020).
} 
KineMaster dan Cap Cut. Aplikasi ini dinilai simple untuk membuat video promosi dan tidak memerlukan anggaran yang besar ${ }^{20}$

c. Wawancara

Untuk mendapatkan data yang valid terkait kondisi industri gerabah yang ada di dusun Pungkang, penulis langsung bertemu dengan mitra yakni pengrajin, pengepul dan lembaga yang menaungi industri gerabah, dari sini penulis banyak mendapatkan informasi verbal yang belum banyak dipublikasikan.

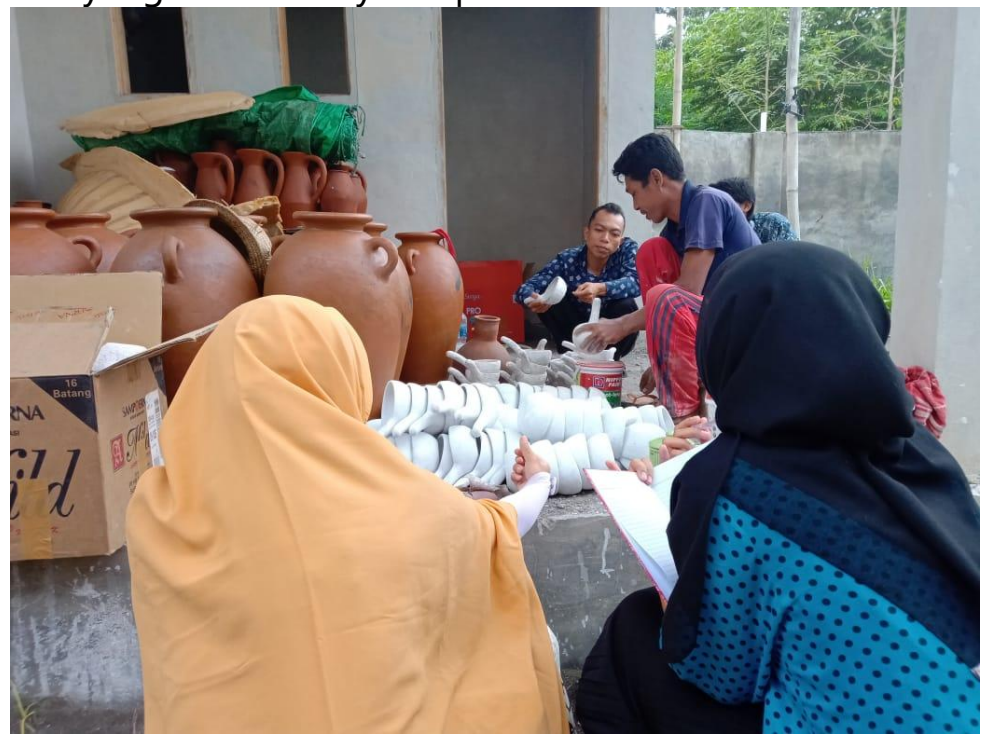

Gambar 2. Wawancara Dengan Salah Satu Pelaku Industri Gerabah

Menggali lebih dalam informasi dari pengrajin dengan berkunjung langsung ke tempat pembuatan gerabah selain melihat proses panjang sebelum gerabah dipasarkan. Dari wawancara ini penulis dapat mengetahui permasalahan yang masih menjadi pekerjaan rumah bagi pemerintah, salah satunya adalah regenerasi dan komunikasi pentingnya gerabah sebagai penyangga ekonomi desa Masbagik Timur.

2. Tahap Produksi

Tahap kedua dalam kegiatan pengabdian ini adalah produksi video promosi, produksi dilakukan sesuai anggaran dan mapping plan yang sudah disusun. Dalam membuat video promosi tidak boleh melakukan tahapan-tahapan yang sembarangan. Untuk dapat mencapai tujuan dari promosi, produksi video promosi harus melalui beberapa tahap diantaranya:

a. Pengambilan gambar/bahan video

Pengambilan bahan berupa potongan-potongan video dan gambar dilakukan langsung ke lokasi pembuatan gerabah di rumah-rumah pengrajin, artshop gerabah, showroom dan tempat strategis yang memungkinkan untuk mudah memberikan informasi terkait dusun Pungkang. Teknik pengambilan bahan video dilakukan dengan teknik live shoot untuk mendapatkan hasil yang real, sehingga terhindar dari illustration view ${ }^{21}$. Kwalitas gambar yang dihasilkan sangat tergantung dengan kondisi di lapangan,

\footnotetext{
${ }^{20}$ Hafizatul Khaira, "Pemanfaatan Aplikasi Kinemaster Sebagai Media Pembelajaran Berbasis ICT" Prosiding Seminar Nasional PBSI-III Tahun 2020 Tema: Inovasi Pembelajaran Bahasa dan Sastra Indonesia Guna Mendukung Merdeka Belajar pada Era Revolusi Industry 4.0 dan Society

${ }^{21}$ R. Bagus Subekti Wicaksana, Agus Purwanto,"Pembuatan Video Profil Tempat Wisata Unggulan Di Klaten Sebagai Media Promosi” Jurnal Ilmiah DASI Vol. 14 No. 04 Desember 2013, hlm 37 - 39
} 
kualitas kamera akan mempengaruhi hasil pengambilan gambar. Berikut merupakan proses pengambilan gambar dengan teknik shoot live:
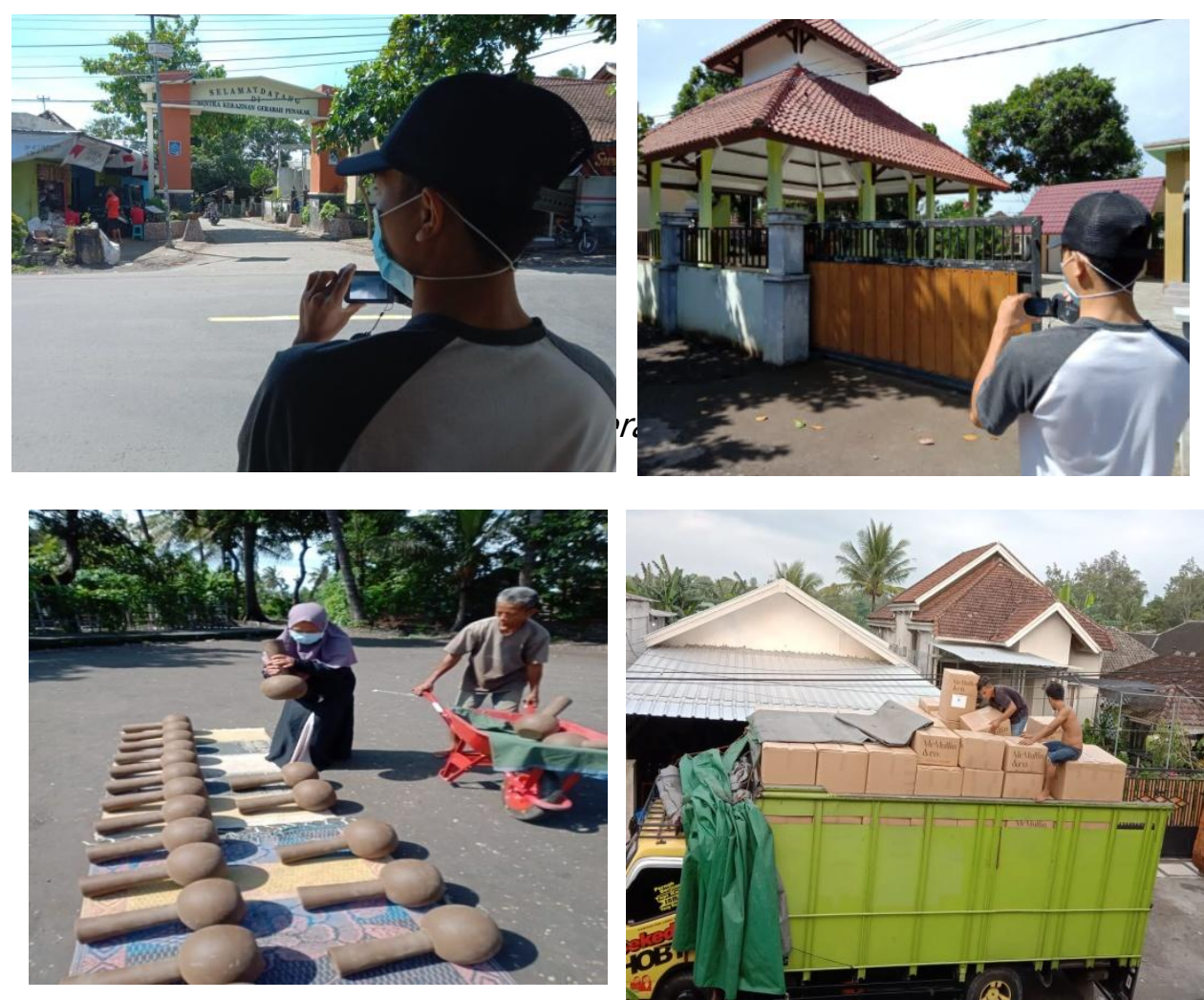

Gambar 4. Penjemuran Gerabah dan Packaging Ekspor Gerabah

b. Scripting

Merupakan proses menuangkan ide dalam bentuk naskah yang menjadi narasi daripada video promosi, untuk menjelaskan isi video sesuai dengan kebutuhan promosi. 


\section{c. Editing}

Editing dilakukan setelah mengumpulkan bahan mentah video dan penggabungan seluruh bahan video yaitu audio, narasi dan gambar. Berikut merupakan gambar tahap-tahap untuk proses editing:
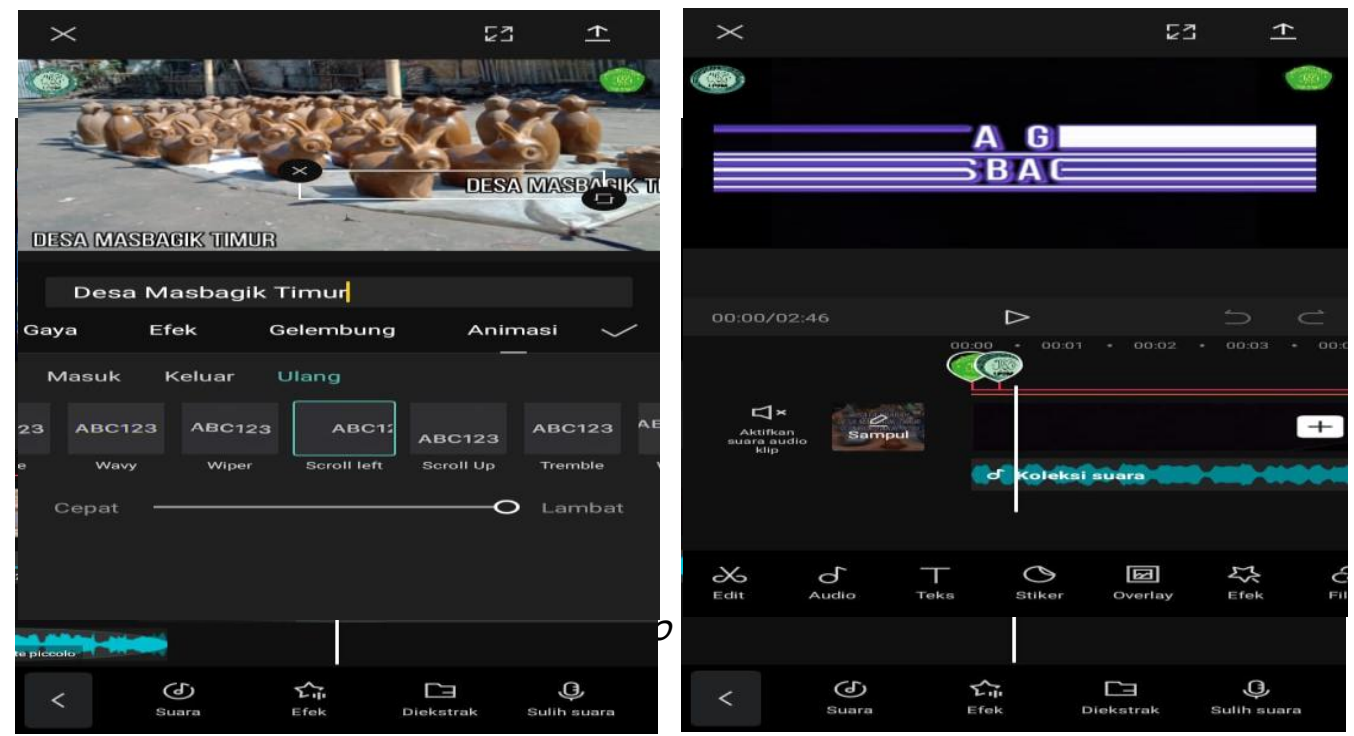

Gambar 5 merupakan cara yang paling popular untuk membuat sebuah video, namun untuk mendapatkan video yang berkualitas membutuhkan keterampilan khusus. Proses editing tersebut setidaknya memakan waktu satu hari untuk membuat video menjadi layak untuk dipublikasikan.

\section{Tahap Refleksi/Evaluasi}

Tahap akhir dari kegiatan pengabdian masyarakat ini adalah refleksi atau evaluasi dengan melihat respon dari mitra pengabdian baik dari pemerintah desa Masbagik Timur lewat lembaga POKDARWIS (Kelompok Sadar Wisata) sebagai fasilitator industri kerajinan gerabah dan pelaku industri gerabah.

Pada tahap ini penulis melakukan koordinasi dengan semua pihak yang berkaitan dengan kegiatan pengabdian kepada masyarakat ini untuk memperoleh data terakhir dalam evaluasi penelitian ini. Berdasarkan hasil pendampingan ini, mitra dari kegiatan ini yang terdiri dari POKDARWIS serta pelaku industry gerabah di dusun Pungkang sudah mampu mempromosikan gerabah yang ada di dusun Pungkang secara mandiri dengan menggunakan media video dengan memanfaatkan platform-platform yang tersedia, seperti media sosial Facebook. 


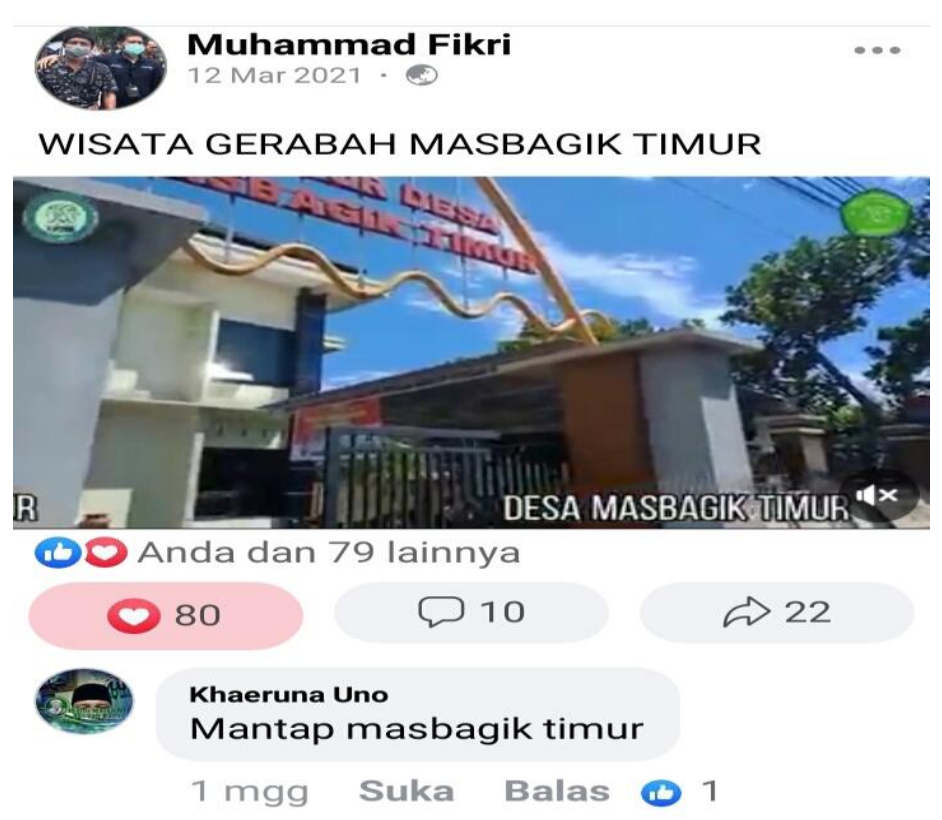

Gambar 6 di atas merupakan salah satu contoh promosi dengan platform Facebook, video promosi tersebut sudah ditonton sebanyak 575 kali dan berhasil di share sebanyak 22 kali. Masyarakat dusun Pungkang mendapatkan manfaat bahwa informasi gerabah dusun Pungkang dapat dikenal tidak lagi hanya fokus pada gerabah yang ada di dusun Penakak.

Pada bagian ini uraikanlah bagaimana kegiatan dilakukan untuk mencapai tujuan. Jelaskan indikator tercapainya tujuan dan tolak ukur yang digunakan untuk menyatakan keberhasilan dari kegiatan pengabdian yang telah dilakukan. Ungkapkan keunggulan dan kelemahan luaran atau fokus utama kegiatan apabila dilihat kesesuaiannya dengan kondisi masyarakat di lokasi kegiatan. Jelaskan juga tingkat kesulitan pelaksanaan kegiatan maupun produksi barang dan peluang pengembangannya kedepan. Artikel dapat diperkuat dengan dokumentasi yang relevan terkait jasa atau barang sebagai luaran, atau fokus utama kegiatan. Dokumentasi dapat berupa gambar proses penerapan atau pelaksanaan, gambar prototype produk, tabel, grafik, dan sebagainya.

\section{KESIMPULAN}

Kegiatan pengabdian kepada masyarakat di dusun Pungkang desa Masbagik Timur telah melewati tahapan-tahapan yang sudah disusun secara sistematis dan terstruktur. Promosi merupakan salah satu cara yang dapat meningkatkan perkembangan suatu usaha, upaya promosi dapat dilakukan dengan beragam cara, termasuk diantaranya melalui media video. Hasil dari penelitian kegiatan pengabdian masyarakat ini menemukan bahwa mitra pengabdian yang terdiri dari POKDARWIS dan pelaku industri gerabah yang ada di dusun Pungkang telah mampu mempromosikan gerabahnya dengan menggunakan media video secara mandiri dan, sehingga video promosi tersebut sudah mampu meluruskan paradigma masyarakat terkait lokasi dan kondisi industri gerabah yang ada di desa Masbagik Timur, dan masyarakat mendapatkan edukasi terkait strategi promosi gerabah mereka dengan memanfaarkan kemajuan tekhnologi masa kini.

Dari temuan tersebut, maka diharapakan agar pemerintah dan para pelaku industri kerajinan tangan gerabah selalu berkomitmen untuk memperkuat koneksi. 
Pemerintah melalui lembaga POKDARWIS (Kelompok Sadar Wisata) senantiasa menjaga eksistensi gerabah sebagai produk khas desa Masbagik Timur dan mengajak para pelaku industri gerabah untuk berpartisipasi dalam promosi baik secara manual maupun berbasis online seperti pembuatan video promosi. Pokdarwis juga harus memperhatikan kebutuhan daripada para pengrajin gerabah di desa Masbagik Timur termasuk dalam hal pemasaran (promosi).

\section{UCAPAN TERIMA KASIH}

Penulis penelitian pengabdian masyarakat sebagai instrumen penelitian pengabdian masyarakat mengucapkan terimakasih kepada Lembaga Penelitian dan Pengabdian Kepada Masyarakat (LPPM) Sekolah Tinggi Agama Islam Darul Kamal NW (STAI Darul Kamal NW Kembang Kerang NTB) yang telah memberikan izin untuk melakukan kegiatan ini. Dan penulis juga mengucapkan terimakasih kepada mitra pengabdian dusun Pungkang desa Masbagik Timur yang terdiri atas pemerintah desa Masbagik Timur, Pokdarwis (Kelompok Sadar Wisata) desa Masbagik Timur, dan para pelaku kerajian gerabah yang ada di dusun Pungkang desa Masbagik Timur. Semoga dengan adanya kegiatan pengabdian yang dilakukan ini memberikan dampak positif dan perkembangan yang lebih baik kedepannya bagi pemerintah desa Masbagik Timur pada umumnya dan pelaku industri gerabah dusun Pungkang pada khususnya.

\section{DAFTAR PUSTAKA}

Ahyani, Hidayatul. "Peranan Pemerintah Dalam Pengembangan Industri Kecil Gerabah Didesa Banyumulek Kecamatan Kediri Kabupaten Lombok Barat " Journal Ilmiah Rinjani Universitas Gunung Rinjani Volume 7. No.2 (2019).

Bachri Prastyoko, Febryandi, Dahlan Fanani dan M. Kholid Mawardi "Strategi Pemasaran Kerajinan Gerabah yang Berorientasi Ekspor pada PT. Lombok Putri Cinderamata " Jurnal Administrasi Bisnis (JAB) Vol. 30 No. 1 (2016).

Bungin, H.M Burhan, "Penelitian Kualitatif : Komunikasi, Ekonomi, Kebijakan Publik, dan Ilmu Sosial Lainnya". Jakarta, Kencana Media Group (2011).

Febrina, Ririn, "Peranan Pemerintah Desa Terhadap Promosi Kerajinan Gerabah (Studi Kasus di Penakak Desa Masbagik Timur Kecamatan Masbagik Kabupaten Lombok Timur" Skripsi, Fakultas Administrasi Publik Universitas Nahdlatul Wathan Mataram(2020).

Khaira, Hafizatul, "Pemanfaatan Aplikasi Kinemaster Sebagai Media Pembelajaran Berbasis ICT" Prosiding Seminar Nasional PBSI-III Tahun 2020 Tema: Inovasi Pembelajaran Bahasa dan Sastra Indonesia Guna Mendukung Merdeka Belajar pada Era Revolusi Industry 4.0 dan Society.

Ponimin, Triyono Widodo, dan Oktaviviana Asmi Nusantari "Pengembangan Desain Gerabah Tradisional Sentra Pagelaran Malang dengan Teknik Aplikasi Serat Alam Melalui Program Kemitraan Masyarakat" Jurnal Imajinasi Vo 1. XIII No. 2 (2019).

Rangky, Freddy, "Strategi Promosi Yang Kreatif Dan Analisis Kasus Integrated Marketing Communication" Jakarta. Penerbit Gramedia Pustaka Utama (2009).

Rapii, Muhammad dkk, "Pemberdayaan Usaha Pengrajin Gerabah "penakak" Di tengah Covid19 Di Desa Masbagik Timur" Jurnal ABDIDAS Vol. 1 No. 6 (2020). 
Rima Melati, Karina, "Perancangan dan Implementasi Perencanaan Bisnis dan Strategi Promosi bagi Kelompok Rintisan Usaha Mandiri Sanggar Batik Jenggolo dan Sekar Arum di Kota Yogyakarta" , Indonesian Journal of Community Engagement Vol. 02, No. $02(2017)$

Tri Harnie, Luluk Jum 'eh Dan Alexandra Hukom, "Pendampingan dalam Memasarkan Produk Hasil Usaha UKM melalui Penggunaan Media Sosial di Kabupaten Gunung Mas Kalimantan Tengah" Jurnal ENGAGEMENT Jurnal Pengabdian Kepada Masyarakat Vol04, No. 01: 51 - 59 (2020).

Subekti Wicaksana, R. Bagus, Agus Purwanto "Pembuatan Video Profil Tempat Wisata Unggulan Di Klaten Sebagai Media Promosi" Jurnal IImiah DASI Vol. 14 No. 04 Desember 2013, h/m $37-39$

Sugyono, "Metode Penelitian Pendidikan (Kuantitatif, Kualitatif, Kombinasi, R\&D dan Penelitian Pendidikan)". Bandung, Penerbit Alfabeta (2019).

Syamsuri "Pola Strategi Promosi Dalam Proses Pemasaran Gerabah Kasongan: Studi Kasus UMKM Sentra Industri Keramik Di Kasongan, Kabupaten Bantul, D.I. Jogjakarta" Jurnal Administrasi Bisnis (JAB)/Vol. 30 No. 1 Januari 2016 diakses di administrasibisnis.studentjournal.ub.ac.id 44. 